\title{
TANGGUNG JAWAB HUKUM PERAWAT MATERNITAS DALAM MELAKUKAN TINDAKAN KEBIDANAN DI BIDANG PERSALINAN
}

\section{Adibah Enggar Sulistiorini}

Fakultas Hukum, Universitas Hang Tuah Surabaya,

Email : adibahenggar@gmail.com

DOI: https://doi.org/10.23917/laj.v4i2.8684

\author{
Submission \\ Track: \\ Received: \\ 20 Agustus 2019 \\ Final Revision: \\ 27 September 2019 \\ Available online: \\ 10 Oktober 2019 \\ Corresponding \\ Author:
}

Adibah Enggar

Sulistiorini

adibahenggar@gmail.com

\section{ABSTRAK}

Spesialisasi keperawatan maternitas diharapkan mampu menjawab kebutuhan masyarakat akan kesehatan reproduksi. Akan tetapi ditemukan beberapa kompetensi yang sama dengan dengan profesi kebidanan. Bidan berwenang dalam pelayanan terkait kespro begitupun perawat maternitas. Salah satu kompetensi yang sama adalah pertolongan persalinan sehingga bisa saja terjadi konflik antarprofesi. Untuk itu diperlukan adanya regulasi atau aturan yang dapat dijadikan landasan perawat maternitas agar bekerja sesuai dengan kewenangannya. Penelitian ini bertujuan untuk menganalisis hak dan kewajiban perawat maternitas dan menemukan jawaban atas tanggung jawab perawat maternitas dalam melakukan tindakan persalinan. Hasil dari penelitian Hasil penelitian menunjukan bahwa perawat maternitas dalam melakukan praktik diluar kewenangannya dapat diminta pertanggungjawaban hukum secara pidana, perdata dan adminstrasi, oleh karena itu sangat diharapkan bagi pemerintah untuk dapat memberikan kewenangan pada perawat maternitas agar bekerja sesuai kompetensi yang dimiliki, serta membuat kebijakan atau regulasi sehingga dalam peraturan perundang-undangan dapat dijelaskan mengenai perlindungan hukum dan legalitas bagi perawat maternitas dalam melakukan pertolongan persalinan, sehingga adanya kekuatan hukum bagi 
perawat maternitas dalam melakukan pelayanan

kesehatan.

Kata Kunci:.tanggung jawab hukum, perawat, maternitas, kebidanan, persalinan

\section{A. PENDAHULUAN}

Pendidikan keperawatan yang memberikan kompetensi pelayanan kespro utamanya adalah pada keperawatan maternitas. Keperawatan maternitas merupakan salah satu bentuk pelayanan profesional keperawatan yang ditujukan kepada wanita pada masa usia subur (WUS) berkaitan dengan sistem reproduksi, kehamilan, melahirkan, nifas, antara dua kehamilan dan bayi baru lahir sampai umur 40 hari, beserta keluarganya, berfokus pada pemenuhan kebutuhan dasar dalam beradaptasi secara fisik dan psikososial untuk mencapai kesejahteraan keluarga dengan menggunakan pendekatan proses keperawatan.(World Health Organization (WHO), 2010) Untuk melaksanakan tanggung jawab tersebut maka program pendidikan spesialis keperawatan maternitas merupakan program studi yang ditujukan untuk menghasilkan spesialis keperawatan maternitas yang professional memiliki tanggung jawab dan tanggung gugat yang diharapkan dapat berperan aktif dalam mengatasi permasalahan kesehatan perempuan di Indonesia.(Goverment in South of Australia, 2010)

Tugas dan kewenangan bidan telah diatur dalam Undang-undang No.4 tahun 2019 tentang Kebidanan (selanjutnya disebut UU Kebidanan) sehingga jelas memberikan arahan dalam kegiatan praktik kebidanan. Berbeda dengan keperawatan maternitas yang secara riil belum termuat dalam Undang-undang No.38 tahun 2014 tentang Keperawatan (selanjutnya disebut UU Keperawatan). UU Keperawatan merupakan upaya perlindungan hukum yang dibentuk dengan adanya profesi keperawatan. Terkait tugas dan kewenangan perawat maternitas belum diatur dalam UU Keperawatan, dalam menjalankan praktiknya perawat maternitas beracuan pada kompetensi klinik perawat maternitas yang termuat dalam Peraturan Menteri Kesehatan Nomor 10 tahun 2015 tentang Standar Pelayanan Keperawatan Di Rumah Sakit Khusus. Tujuan dari penilitian ini adalah untuk menganalisis hak dan kewajiban perawat maternitas dan menemukan jawaban atas tanggung jawab perawat maternitas dalam melakukan tindakan persalinan.

\section{B. METODE PENELITIAN}

Penelitian ini menggunakan pendekatan perundang- undangan (Statute Approach), dan pendekatan konseptual (Conseptual Approach). Pertama, pendekatan perundang -undangan akan dilakukan dengan menggunakan legislasi dan regulasi yang digunakan untuk menemukan konsep-konsep/ teori-teori yang mendukung sehingga membuka kesempatan untuk mempelajari adakah konsistensi dan kesesuaian antara suatu undang- undang dengan undang-undang lainnya.(Peter Mahmud Marzuki, 2014a) Untuk penelitian ini digunakan pendekatan perundang-undangan antara Undang-Undang Kesehatan, Undang-Undang Keperawatan, Undang-Undang Kebidanan, Undang-Undang Tenaga Kesehatan Peraturan Pemerintah, Keputusan Menteri Kesehatan Indonesia dalam menetapkan tanggung jawab hukum. Kedua, pendekatan konseptual bersumber dari pandangan-pandangan dan doktrindoktrin yang berkembang di dalam ilmu hukum sehingga akan menemukan ide-ide yang melahirkan pengertian hukum, konsep hukum dan asas hukum yang relevan dengan isu yang dihadapi.(Peter Mahmud Marzuki, 2014b) 


\section{PEMBAHASAN}

\section{Kewajiban Perawat Maternitas Dalam Melakukan Tindakan Persalinan}

Perawat berkewajiban untuk memberikan pelayanan keperawatan sesuai dengan standar profesi, standar praktek keperawatan, kode etik, dan SOP serta kebutuhan klien atau pasien dimana standar profesi, standar praktek dan kode etik yang ditetapkan oleh organisasi profesi merupakan pedoman yang harus diikuti oleh setiap tenaga keperawatan untuk melaksanakan praktik keperawatan. Perawat yang melaksanakan tugasnya diwajibkan untuk merujuk klien dan atau pasien ke fasilitas pelayanan kesehatan yang mempunyai keahlian atau kemampuan yang lebih baik, apabila tidak mampu melakukan suatu pemerikasaan atau tindakan. Hal ini juga tergantung situasi, jika lingkungan kita juga tidak memungkinkan maka kita sebagai perawat dapat menerangkan alasan yang tepat.

Perawat berkewajiban untuk merahasiakan segala sesuatu yang diketahuinya tentang klien dan atau pasien, kecuali untuk kepentingan hukum. Hal ini menyangkut privasi klien yang berada dalam asuhan keperawatan karena disisi lain perawat juga wajib menghormati hak-hak klien dan atau pasien dan profesi lain sesuai dengan ketentuan dan peraturan yang berlaku. Kewajiban perawat maternitas sendiri mengacu pada implementasi keperawatan pada standar pelayanan keperawatan ibu dan anak yang tertera dalam Peraturan Menteri Kesehatan Nomor 10 tahun 2015 tentang Standar Pelayanan Keperawatan Di Rumah Sakit Khusus. Dalam Pasal 37 UU Keperawatan menyebutkan untuk mewajibkan perawat melengkapi sarana dan prasarana pelayanan keperawatan sesuai dengan standar pelayanan keperawatan, memberikan pelayanan, merujuk klien kepada perawat lain yang tepat sesuai dengan keahliannya, membuat dokumentasi asuhan keperawatan, memberikan informasi yang lengkap jujur, benar, jelas, dan mudah dimengerti mengenai tindakan keperawatan kepada klien atau keluarganya sesuai dengan batas kewenangannya, melaksanakan tindakan pelimpahan wewenang dari tenaga kesehatan lain sesuai dengan kompetensi perawat, dan melaksanakan penugasan khusus yang ditetapkan oleh pemerintah.

Dengan penjelasan tersebut, perawat dapat melaksanakan standar pelayanan keperawatan yang apabila terjadi kesalahan dapat dimintai pertanggung jawabannya. Karena itulah, adanya hak dan kewajiban perawat memiliki hubungan dengan masyarakat dan dilindungi oleh hukum, dan perawat wajib untuk mentaati hubungan tersebut. Sebenarnya dalam kewajiban perawat maternitas tidak disebutkan bahwa perawat maternitas boleh melakukan pertolongan persalinan. Namun pada kenyataannya perawat maternitas memiliki kompetensi dalam melakukan pertolongan persalinan. Kompetensi pertolongan persalinan diberikan kepada perawat klinik maternitas II apabila tidak ada tenaga kesehatan yang berwenang dalam melakukan pertolongan persalinan.

\section{Tanggung Jawab Hukum Secara Pidana Perawat Maternitas Dalam Melakukan Tindakan Persalinan}

Sebagai salah satu tenaga kesehatan, perawat maternitas dalam menjalankan praktiknya harus dilakukan sesuai dengan kewenangan yang didasarkan pada kompetensi yang dimilikinya. Dalam hal ini perawat maternitas memiliki kompetensi untuk menolong persalinan, tetapi tidak memiliki kewenangan untuk melakukan pertolongan persalinan. Namun menurut Pasal 30 ayat 1 huruf g UU Keperawatan disebutkan bahwa perawat berwenang memberikan tindakan pada keadaan gawat darurat sesuai kompetensinya. Melihat pada ketentuan di atas, sehubungan dengan pertolongan persalinan oleh perawat maternitas, dapat dilihat bahwa tanggung jawab hukum secara pidana akan diberikan 
kepada perawat maternitas jika tindakan yang dilakukannya tidak dalam kondisi gawat darurat dan terjadi culpa lata atau kesalahan yang bersifat mencolok dan dapat mengakibatkan cacat baik permanen maupun tidak dan juga terjadi kematian dalam melakukan pertolongan persalinan tersebut. Jika dalam melakukan pertolongan persalinan oleh perawat maternitas tidak dalam keadaan darurat dan terjadi culpa lata maka tanggung jawab pidana yang dapat dijatuhkan pada perawat maternitas merujuk pada ketentuan pidana pada UU Tenaga Kesehatan Pasal 84

(1) Setiap Tenaga Kesehatan yang melakukan kelalaian berat yang mengakibatkan Penerima Pelayanan Kesehatan luka berat dipidana dengan pidan penjara paling lama 3 (tiga) tahun.

(2) Jika kelalaian berat sebagaimana dimaksud pada ayat (1) mengakibatkan kematian, setiap Tenaga Kesehatan dipidana dengan pidana penjara paling lama 5 (lima) tahun.

Pengaturan tindakan medis secara umum dalam UU No.23/1992 tentang Kesehatan dapat dilihat dalam pasal 32 ayat (4) yang menyatakan bahwa "pelaksanaan pengobatan dan atau perawatan berdasarkan ilmu kedokteran dan ilmu keperawatan hanya dapat dilakukan oleh tenaga kesehatan yang mempunyai keahlian dan kewenangan untuk itu". Ketentuan tersebut dimaksudkan untuk melindungi masyarakat dari tindakan seseorang yang tidak mempunyai keahlian dan kewenangan untuk melakukan pengobatan/perawatan, sehingga akibat yang dapat merugikan atau membahayakan terhadap kesehatan pasien dapat dihindari, khususnya tindakan medis yang mengandung risiko. Pengaturan kewenangan tenaga kesehatan dalam melakukan tindakan medik diatur dalam pasal $50 \mathrm{UU}$ No.23/ 1992 tentang Kesehatan yang merumuskan bahwa "tenaga kesehatan bertugas menyelenggarakan atau melakukan kegiatan kesehatan sesuai dengan bidang keahlian dan atau kewenangan tenaga kesehatan yang bersangkutan”.

\section{Tanggung Jawab Hukum Secara Perdata Perawat Maternitas Dalam Melakukan Tindakan Persalinan}

Gugatan keperdataan terhadap perawat bersumber pada dua bentuk yakni perbuatan melanggar hukum (onrechtmatigedaad) dan perbuatan wanprestasi (contractual liability).

a. Tanggung Jawab Hukum Akibat Perbuatan Melanggar Hukum

Terdapat 3 prinsip sanksi hukum bidang hukum perdata apabila seorang perawat maternitas dalam melakukan perbuatannya disebut melanggar hukum yang diatur dalam Pasal 1365, 1366, 1367 Kitab Undang-Undang Hukum Perdata yaitu sebagai berikut:

1) Pertanggungjawaban langsung dan mandiri (personal liability) berdasarkan Pasal 1365 BW dan Pasal 1366 BW "Setiap tindakan yang menimbulkan kerugian atas diri orang lain berarti orang yang melakukannya harus membayar kompensasi sebagai pertanggungjawaban kerugian dan seseorang harus bertanggungjawab tidak hanya karena kerugian yang dilakukannya dengan sengaja, tetapi juga karena kelalaian atau kurang berhati-hati"

Berdasarkan ketentuan pasal tersebut maka seorang perawat maternitas yang melakukan kesalahan dalam menjalankan fungsi independennya yang mengakibatkan kerugian pada pasien maka ia wajib memikul tanggungjawabnya secara mandiri. Dilihat dari ketentuan Pasal 1365 KUHPerdata di atas maka pertanggungjawaban perawat maternitas tersebut lahir apabila memenuhi empat unsur yakni (Moegni Djijidihardjo, 1979):

1) Perbuatan itu melanggar hukum

2) Pasien harus mengalami suatu kerugian 
3) Perbuatan harus dilakukan dengan kesalahan

4) Ada hubungan kausal antara kesalahan dengan kerugian

Mengenai apa yang dimaksud dengan perbuatan melanggar hukum, undang-undang tidak memberikan perumusannya. Namun sesuai dengan yurisprudensi Arrest Hoge Raad 31 Januari 1919 (Cecep Triwibowo, 2010) ditetapakan adanya empat kriteria perbuatan melanggar hukum yaitu:

1) perbuatan itu bertentangan dengan kewajiban hukum si pelaku

2) perbuatan itu melanggar hak orang lain

3) perbuatan itu melanggar kaedah tata susila

4) perbuatan itu bertentangan dengan asas kepatutan, ketelitian serta sikap hati-hati yang seharusnya dimiliki seseorang dalam pergaulan dengan sesama warga masyarakat atau terhadap harta benda orang lain.

a. Pertanggungjawaban dengan asas respondeat superior atau vicarious liability, melalui Pasal 1367 BW yang menyebutkan bahwa "Seseorang harus memberikan pertanggungjawabkan tidak hanya atas kerugian yang ditimbulkan dari tindakannya sendiri, tetapi juga atas kerugian yang ditimbulkan dari tindakan orang lain yang berada dibawah pengawasannya"

Bila dikaitkan dengan pelaksanaan fungsi perawat maternitas maka kesalahan yang terjadi dalam menjalankan fungsi interdependen perawat maternitas akan melahirkan bentuk pertanggungjawaban di atas. Sebagai bagian dari tim maupun orang yang bekerja di bawah perintah dokter/rumah sakit, maka perawat maternitas akan bersama-sama bertanggung gugat kepada kerugian yang menimpa pasien.

b. Pertanggungjawaban dengan asas zaakwarneming berdasarkan Pasal 1354 BW "Jika seorang dengan sukarela, dengan tidak mendapat perintah untuk itu, mewakili urusan orang lain dengan atau tanpa pengetahuan orang ini, maka ia secara diam-diam mengikat dirinya untuk meneruskan serta menyelesaikan urusan tersebut, hingga orang yang diwakili kepentingannya dapat mengerjakan sendiri urusan itu. la memikul segala kewajiban yang harus dipikulnya, seandainya ia kuasakan dengan suatu pemberian kuasa yang dinyatakan dengan tegas"

Dalam hal ini konsep pertanggungjawaban terjadi seketika bagi seorang perawat yang berada dalam kondisi tertentu harus melakukan pertolongan darurat dimana tidak ada orang lain yang berkompeten untuk itu. Perlindungan hukum dalam tindakan zaarwarneming perawat tersebut tertuang dalam Pasal 35 UU Keperawatan

(1) Dalam keadaan darurat untuk memberikan pertolongan pertama, Perawat dapat melakukan tindakan medis dan pemberian obat sesuai dengan kompetensinya.

(2) Pertolongan pertama sebagaimana dimaksud pada ayat (1) bertujuan untuk menyelamatkan nyawa Klien dan mencegah kecacatan lebih lanjut.

(3) Keadaan darurat sebagaimana dimaksud pada ayat (1) merupakan keadaan yang mengancam nyawa atau kecacatan Klien.

(4) Keadaan darurat sebagaimana dimaksud pada ayat (1) ditetapkan oleh Perawat sesuai dengan hasil evaluasi berdasarkan keilmuannya.

(5) Ketentuan lebih lanjut mengenai keadaan darurat sebagaimana dimaksud pada ayat (1) diatur dengan Peraturan Menteri.

Perawat justru akan dimintai pertanggungjawaban hukum apabila tidak mengerjakan apa yang seharusnya dikerjakan dalam Pasal 35 UU Keperawatan tersebut.

1. Perbuatan Wanprestasi 
Menurut ilmu hukum perdata, seseorang dapat dianggap melakukan wanprestasi apabila tidak melakukan apa yang disanggupi akan dilakukan, melakukan apa yang dijanjikan tetapi terlambat dan melaksanakan apa yang dijanjikan, tetapi tidak sebagai mana dijanjikan serta melakukan sesuatu yang menurut perjanjian tidak boleh dilakukannya. (Subekti, 1990)

Gugatan berdasarkan wanprestasi seorang perawat akan dimintai pertanggungjawaban apabila terpenuhi unsur-unsur wanprestasi yaitu:

a. Tidak mengerjakan kewajibannya sama sekali; dalam konteks ini apabila seorang perawat tidak mengerjakan semua tugas dan kewenangan sesuai dengan fungsi, peran maupun tindakan keperawatan

b. Mengerjakan kewajiban tetapi terlambat; dalam hal ini apabila kewajiban sesuai fungsi tersebut dilakukan terlambat yang mengakibatkan kerugian pada pasien.

c. Mengerjakan kewajiban tetapi tidak sesuai dengan yang seharusnya; suatu tugas yang dikerjakan asal-asalan.

d. Mengerjakan yang seharusnya tidak boleh dilakukan; dalam hal ini apabila seorang perawat melakukan tindakan medis yang tidak mendapat delegasi dari dokter.

Pada dasarnya pertanggung jawaban perdata itu bertujuan untuk memperoleh ganti rugi atas kerugian yang diderita oleh pasien akibat adanya wanprestasi atau perbuatan melawan hukum dari tindakan dokter. Dalam hal ini pasien harus bisa membuktikan bahwa bidan ini benar benar telah mengadakan perjanjian, kemudian dia telah melakukan wanprestasi terhadap perjanjian tersebut yang tentu saja dalam hal ini senantiasa harus didasarkan pada kesalahan profesi. Lalu pasien disini harus mempunyai bukti-bukti kerugian akibat tidak dipenuhinya kewajiban bidan sesuai dengan standard profesi bidan yang berlaku dalam suatu kontrak terapeutik.

Pertanggungjawaban secara perdata diberikan kepada perawat maternitas apabila perawat maternitas dalam melakukan pertolongan persalinan terbukti memenuhi unsur wanprestasi seperti melakukan pertolongan persalinan dalam keadaan darurat namun tidak sesuai dengan standar operasional prosedur. Maka pertanggungjawaban secara perdata tersebut akan dipikul langsung oleh perawat maternitas yang bersangkutan sesuai personal liability.

Undang-Undang Keperawatan sebenarnya telah melindungi dunia kerja Keperawatan. Pasal 36 Perawat dalam melaksanakan Praktik keperawatan berhak memperoleh perlindungan hukum sepanjang melaksanakan tugas sesuai dengan standar pelayanan, standar profesi, standar prosedur operasional, dan ketentuan Peraturan Perundang undangan. Baik praktek di Fasilitas kesehatan maupun praktek di masyarakat. Secara tertulis hubungan kerja antara pasien dengan perawat dalam Undang-Undang Keperawatan termasuk dalam jenis perjanjian Inspanningsverbintenis. Yaitu perjanjian yang mendasarkan kepada usaha para pihak yang maksimal, artinya perjanjian upaya yakni kedua belah pihak berjanji atau sepakat untuk berdaya upaya secara maksimal guna mewujudkan apa yang diperjanjikan.

\section{Tanggung Jawab Hukum Secara Administrasi Perawat Maternitas Dalam Melakukan Tindakan Persalinan}

Perawat maternitas dikatakan telah melakukan pelanggaran administrasi manakala perawat tersebut telah melanggar hukum administrasi. Secara prinsip, pertanggungjawaban hukum administrasi lahir karena adanya pelanggaran terhadap ketentuan hukum administrasi terhadap penyelenggaraan praktik perawat berdasarkan ketentuan yang berlaku. Permenkes No. 148/2010 telah memberikan ketentuan administrasi yang wajib ditaati perawat yakni:

a. Surat Izin Praktik Perawat bagi perawat yang melakukan praktik mandiri. 
b. Penyelengaraan pelayanan kesehatan berdasarkan kewenangan yang telah diatur dalam Pasal 8 dan Pasal 9 dengan pengecualian Pasal 10

c. Kewajiban untuk bekerja sesuai standar profesi

Ketiadaan persyaratan administrasi di atas akan membuat perawat rentan terhadap gugatan malpraktik. Ketiadaan SIPP dalam menjalankan penyelenggaraan pelayanan kesehatan merupakan sebuah administrative malpractice yang dapat dikenai sanksi hukum. Bentuk Sanksi administrasi yang diancamkan pada pelanggaran hukum adminitarsi ini adalah:
a. Teguran lisan;
b. Teguran tertulis;
c. Pencabutan izin SIKP dan SIPP

Menurut peratuan yang berlaku, seseorang yang telah lulus dan dinyatakan sebagai perawat, harus mendapatkan lisensi agar memperoleh ijin bekerja atau yang biasa disebut SIPP (Surat Ijin Praktik Perawat). Tidak dibenarkan melakukan pelayanan diluar batas kewenangan seorang perawat, jika ketentuan tersebut dilanggar maka perawat dianggap telah melakukan administrative malpractice dan dapat dikenai sanksi administrative.

Dalam praktek pelaksanaannya tanggung jawab secara administrasi ini dapat diberikan kepada perawat maternitas jika perawat tersebut melakukan pertolongan persalinan yang tidak sesuai dengan kewenangannya bukan dalam keadaan darurat dan dilakukan pada praktik mandiri tidak dalam keadaan keterbatasan tertentu.

Apabila seseorang bersedia menolong orang lain dalam keadaan darurat, maka ia harus melakukannya hingga tuntas dalam arti ada pihak lain yang melanjutkan pertolongan itu atau korban tidak memerlukan pertolongan lagi. Dalam hal pertolongan tidak dilakukan dengan tuntas maka pihak penolong dapat digugat karena dianggap mencampuri/ menghalangi kesempatan korban untuk memperoleh pertolongan lain (Is, 2015)

Di USA dikenal penerapan doktrin Good Samaritan dalam peraturan perundangundangan pada hampir seluruh negara bagian. Doktrin tersebut terutama diberlakukan dalam fase pra-rumah sakit untuk melindungi pihak yang secara sukarela beritikad baik menolong seseorang dalam keadaan gawat darurat. (Hanafiah, M. Jusuf, 2016)

Dengan demikian seorang pasien dilarang menggugat dokter atau tenaga kesehatan lain untuk kecederaan yang dialaminya. Dua syarat utama doktrin Good Samaritan yang harus dipenuhi adalah:

a. Kesukarelaan pihak penolong. Kesukarelaan dibuktikan dengan tidak ada harapan atau keinginan pihak penolong untuk memperoleh kompensasi dalam bentuk apapun. Bila pihak penolong menarik biaya pada akhir pertolongannya, maka doktrin tersebut tidak berlaku.

b. Itikad baik pihak penolong. Itikad baik tersebut dapat dinilai dari tindakan yang dilakukan penolong. Hal yang bertentangan dengan itikad baik misalnya melakukan trakeostomi yang tidak perlu untuk menambah keterampilan penolong.

\section{KESIMPULAN}

Hak perawat maternitas mengacu pada hak perawat secara umum yang terdapat pada Pasal 36 UU Keperawatan. Sedangkan kewajiban perawat maternitas mengacu pada implementasi keperawatan pada standar pelayanan keperawatan ibu dan anak yang tertera pada Peraturan Menteri Kesehatan Nomor 10 tahun 2015 tantang Standar Pelayanan Keperawatan Di Rumah Sakit Khusus. Pertanggungjawaban yang dapat dikenakan oleh perawat adalah bentuk tanggung jawab pidana, perdata dan administrasi. 
Pertanggungjawaban itu akan dipikul langsung dan mandiri oleh perawat maternitas yang bersangkutan sesuai dengan personal liabilit.

\section{E. DAFTAR PUSTAKA}

Undang-Undang Nomor 36 Tahun 2009 Tentang Kesehatan, Lembaran Negara Republik Indonesia Tahun 2009 Nomor 144, Tambahan Lembaran Negara Republik Indonesia Nomor 5063

Undang-Undang Nomor 36 Tahun 2014 tentang Tenaga Kesehatan, Lembaran Negara Republik Indonesia Tahun 2014 Nomor 307, Tambahan Lembaran Negara Republik Indonesia Nomor 5612

Undang-Undang Nomor 38 Tahun 2014 tentang Keperawatan, Lembaran Negara Republik Indonesia Tahun 2014 Nomor 298, Tambahan Lembaran Negara Republik Indonesia Nomor 5607

Undang-Undang Nomor 4 Tahun 2019 tentang Kebidanan, Lembaran Negara Republik Indonesia Tahun 2014 Nomor 56, Tambahan Lembaran Negara Republik Indonesia Nomor 6325

Peraturan Menteri Kesehatan Nomor 10 Tahun 2015 tentang Standar Pelayanan Keperawatan Di Rumah Sakit Khusus Berita Negara Republik Indonesia Tahun 2015 Nomor 434

Cecep Triwibowo (2010) Hukum Keperawatan, Panduan Hukum dan Etika Bagi Perawat. Yogyakarta: Pustaka Book Publisher,.

Goverment in South of Australia (2010) Guide for Maternal and Neonatal Services.

Hanafiah, M. Jusuf, A. A. (2016) Etika Kedokteran \& Hukum Kesehatan. Jakarta: EGC.

Is, M. S. (2015) Etika dan Hukum Kesehatan: Teori dan Aplikasinya di Indonesia. edisi pert. Jakarta: Kencana Prenada Media Group.

Moegni Djijidihardjo (1979) Perbuatan Melawan Hukum. cetakan 1. Jakarta: Pradnya Paramita.

Peter Mahmud Marzuki (2014a) Penelitian Hukum Edisi Revisi. Jakarta: Prenadamedia Group.

Peter Mahmud Marzuki (2014b) Penelitian Hukum Edisi Revisi. Jakarta: Prenadamedia Group.

Subekti (1990) Hukum Perjanjian. Bandung: PT Internusa.

World Health Organization (WHO) (2010) Nursing Midwefery Strategies Direction 2011-2015. Geneva Switchzerland. 